\title{
Re-Branding Zimbabwe: A Transformative and Challenging Process
}

\author{
Dr. Virimai Victor Mugobo \\ Department of Retail Business Management, Faculty of Business, \\ Cape Peninsula University of Technology, South Africa \\ Email: mugobov@cput.ac.za
}

\author{
Dr. Myles Wakeham \\ Senior Lecturer, Faculty of Business, Cape Peninsula University of Technology (CPUT), Engineering Building, \\ Cape Town Campus P. O. Box 652 Cape Town, 8000, South Africa. \\ Email: wakehamm@cput.ac.za
}

\section{Doi:10.5901/mjss.2014.v5n27p298}

\section{Abstract}

During the past few decades, nation branding has emerged as one of the key strategies for national economic development. Many nations across the world, both developed and developing, have embraced the concept as they compete against each other for export markets, foreign direct investment, tourists, scarce human resources and international leverage and influence. This article explores the concept of nation branding and investigates its applicability to Zimbabwe, which has been riddled with various socio-economic and political problems during the past two decades. The main purpose of the study was to develop a model that can be used to re-brand Zimbabwe. This research study adopted a mixed-methods approach through the amalgamation of both qualitative and quantitative research methodologies. According to the research findings, Zimbabwe has a negative image on global map. The country needs to be re-branded and the majority of Zimbabweans are willing to be part of this process. However, for the re-branding initiative to be successful there should be a comprehensive transformation of the country's socio-political, economic and legal systems in order to create an enabling environment that is conducive for the effective application of nation branding strategies. The findings further reinforce the notion that re-branding should be part of a broader national economic development strategy for the country. The research study concludes with the propagation of the proposed transformative process model for the re-branding of Zimbabwe.

Keywords: Nation Branding, Zimbabwe, Transformation, Re-branding, Competitiveness

\section{Introduction}

As competition for export markets, skilled human resources, trade and international dominance continues to increase among nations, it has become imperative for countries across the world to create, nurture and sustain "strong nation brands". The idea of a nation brand has thus gained prominence across the world as governments are realising the importance of creating, nurturing and managing a competitive nation brand especially in view of globalisation and the subsequent gigantic competition for resources and markets. Nation branding is an important topic that has attracted increased interest among nation branding researchers and practitioners during the past two decades (Olins, 1999; Kotler, P. \& Gertner, D. 2002; Anholt, 2004 \& 2007; Szondi, 2007; Dinnie, 2009 and Fan, 2009)

Many academics and practitioners generally agree that nation branding is a practice that can be used to position and re-position a country as a part of an overall national economic development strategy. National economic development hinges on a country's ability to attract foreign investment, tourists, export markets, skilled human resources and many other factors. Just as companies and corporations compete for market share and competitive advantage, countries are now also engaged in accelerated competition against each other for export markets, tourists, skilled human resources and inward investment. Supporting this viewpoint, Kotler, Asplund and Haider (1999: 59) postulate that fierce competition for resources, business relocation, foreign investment, visitors, and even residents, is evident in today's world.

In order to win this socio-economic 'battle of countries', many states are turning to nation branding as a competitive national economic development strategy. Nation branding has, therefore, become ubiquitous across the global economy, and Risen (2005: 215) supports this view when he elucidates that "...just as companies have learnt to 'live the brand', countries should consider their reputations carefully because in the interconnected world, that is what statecraft is all 
about".

Managing national economic development has, therefore, shifted from being a socio-political issue to being a marketing or business challenge, hence the need for countries to be managed as brands. Just as a failing or dying product or service, a brand can be re-branded on the market and it can, therefore, be argued that a failed country or state can also be re-branded in order to revivify it.

Pike (2009: 858) underscores that the perceived value of a place brand is affected by a country's characteristics such as commerce, politics, culture, sport, science and tourism. During the past three decades, Zimbabwe has been bedevilled by a number of socio-economic and political challenges and these include, inter alia, unprecedented inflation, economic mismanagement, unemployment, political unrest, brain drain, suppression of the media and the judiciary, corruption, suspension from multilateral institution and the imposition of economic sanctions on the country. In this regard, nation branding has thus been proposed by academics and practitioners as panacea for the problems a country may face at any particular juncture.

The purpose of this study was therefore to establish and recommend the process that should guide the re-branding of the country in order to restore the country to its former position as an economically stable and developing country. The development of a coherent, comprehensive and effective country brand for Zimbabwe is, therefore, vital for the transformation of the country in order to ensure sustainable economic development.

\section{Background of Zimbabwe as a Brand}

Nation branding is a growing area of study and Vatahov (2006:1) propagates that governments today are tasked with the economic and political development of their countries and, therefore, they should attempt to run the country as efficiently and effectively as possible.

Cromwell and Kyriacou (2004:1) point out that "national development cannot be achieved in isolation of the international community, as markets and foreign policies compete in the international arena. The complexity of these elements and a nation's political, economic, legal and cultural environment all contribute to a nation's identity and image". Using Zimbabwe as the focal point, the research study specifically sought to establish how the country can be re-branded in order to improve its image, revive its economy and create a conducive environment for foreign direct investment (FDI) as well as other economic activities such as attracting tourism, increasing exports and building international relations with other countries.

Place branding is a contemporary discipline that has gained attention worldwide among academics, economists, marketing practitioners, politicians, investors and the general public. For instance, the 2007 World Economic Forum conference in Johannesburg discussed the 'Re-branding of Africa' as one of its agenda items (World Economic Forum, 2007).

Addressing an audience of business executives in Harare, the Prime Minister of Zimbabwe, Morgan Tsvangirai (2009), declared that "...we have to re-brand the country. We have been seriously damaged. We want to see people coming rather than being evacuated from Zimbabwe. We are not at war, and, therefore, there can be no reason for the country to continue to be considered an unsafe tourist destination" (cited in Hungwe (2009:1).

Corroborating the Zimbabwean Prime Minister, the German Ambassador to Zimbabwe, Dr. Albrecht Conze (2009), also pointed out that "...Zimbabwe needs re-branding to give it a positive image and for this re-branding drive to succeed, the country needs to generate a positive story first" (cited by Radio VOP, 2009).

More and more governments are starting to understand that that no country will be able to ignore the way that other countries perceive it (Valentin \& Razvan, nd). A strong brand is a highly valuable national asset. In a time of political, economic and social challenges, effective and efficient nation branding may be a panacea to these challenges, and may bring the required national economic development, social cohesion and improved standards of living for the country's citizens.

According to Eppel (2009:1), the signing of the Global Peace Agreement (GPA) between the Zimbabwe African National Union - Patriotic Front (ZANU - PF) and other opposition parties in Zimbabwe, ushered in the Government of National Unity (GNU), which has the sole mandate of reviving the economy and ensuring peace and stability in the country. Chief among the priorities of this GNU is the need to re-brand the country in order to restore the country's relations with other countries, promote trade and investments and revitalize the economy. However, the process of how the country should be re-branded has not been articulated and remains unknown.

Acknowledging the need for Zimbabwe to be re-branded, Zimbabwe's Deputy Prime Minister, Professor Arthur Mutambara (2009), noted that "...the re-branding of the country is priority number one. We want to re-brand Zimbabwe, but what are we known for? How are we perceived by the rest of the world? We are known for violence, farm invasions, 
disregard for the rule of law, electoral fraud, cholera, an unheard of rocket-propelled inflation, gigantic corruption and mafia-style abductions and kidnappings of journalists, human rights activists and anyone else seeking democratic space" (cited in Mpofu, 2009:7).

It is this background that impelled the researchers to endeavour to establish how Zimbabwe can be re-branded in order to take the country out of its current social, economic and political quagmire. The study specifically sought to establish what process should be followed in re-branding Zimbabwe and how re-branding can help the country overcome the socio-economic and political challenges currently bedevilling it.

Although countries with 'branding problems' face an uphill battle when they try to change the perceptions that others have of them, history has shown that this is possible and that the rewards for those who are able to overcome the problems, are large (Oxford Analytica, nd).

\section{Research Problem}

This study sought to establish how nation branding can be used as a strategy to transform, rejuvenate and reposition Zimbabwe as an effective nation brand through a process of re-branding. The country currently faces various challenges across the social, economic and political spheres and the problem is to establish how re-branding can be used as a strategy to transform Zimbabwe from its current state of affairs to an economically viable, prosperous, and peaceful country that meets the expectations of its citizens and other stakeholders. Therefore, the central question to the study wass: how can the country be re-branded and what process should be followed to ensure effective and efficient transformation that will help the country to overcome the challenges that it is currently facing?

\section{Research Questions}

The main research question for this study is; how can nation branding be used to transform Zimbabwe? In order to answer this question, it was also imperative for the study to determine the process that should guide the re-branding of Zimbabwe. In order to comprehensively answer the main research question, the study also sought to answer the following research sub-questions:

- What is the current context of the brand Zimbabwe and its projection on the global map?

- What process should guide the re-branding of Zimbabwe?

- How can re-branding be used as part of the process to overcome the challenges of transforming Zimbabwe?

- What is the desired effect of nation branding in Zimbabwe?

- What are the challenges of re-branding Zimbabwe?

\section{Research Objectives}

The main objective of this study was to establish how Zimbabwe could be re-branded in order for the country to overcome the socio-economic and political challenges that it is currently facing. The study sought to specifically determine and propose the process that should guide the re-branding of Zimbabwe in order to transform the country through the application of nation branding principles. This study also sought to fulfil the following sub-objectives:

- To analyse the current context of the brand Zimbabwe and its projection on the global map;

- To determine and recommend the process that should guide the re-branding of Zimbabwe;

- To determine how re-branding can be used as part of the process to overcome the challenges of transforming Zimbabwe?

- To establish the desired effect of nation branding in Zimbabwe; and

- To identify the challenges of re-branding Zimbabwe

\section{Literature Review}

Countries have always been marketed since time immemorial, hence Kotler et al. (1999:1) argue that "...the principles of marketing and branding can also be applied for places". De Vicente (2004:1) posits that "... marketing a country is not entirely new; in fact; numerous countries have traditionally promoted their image for tourism". Any nation can be viewed as a brand as it can be viewed as a compound of contemporary and historical associations that have relevance for marketing (O'Shaughnessy \& O'Shaughnessy, 2000:56). 
Arguing that nation branding is not too different from the branding of products or corporations, Olins (2002: 247248) asserts that "...all of us who work with corporations and their brands understand that fizzy drinks, trainers, mobile phones and other apparently insignificant and entirely unmemorable trivia give real emotional and spiritual value to some lives. Many brands help to create a sense of identity, of belonging, just like the nation".

Lee (2009:1) asserts that "...nation branding is about creating a nation's values and benefits for its people, and sustaining its competitiveness". Moilanen and Rainisto (2009:3) postulate that "...countries, cities, regions and tourist resorts face increasing competition when they try to attract tourists, inhabitants and companies to their region or to promote trade".

\subsection{Marketing a country}

According to Wells and Wint (2000), "...the new competitive foreign investment environment has prompted analogies between competition among governments for foreign investment and competition among firms for market share". They further postulate that "...given the similarities in the nature of the competition, it is not surprising that countries are adopting marketing strategies that parallel those of private companies" (ibid).

Hemestrom, Luu and Unenge (2006:4) elucidate that there are several concepts that deal with the marketing of a country. The most significant are nation branding, tourism marketing and destination branding.

\subsection{Destination/place branding}

A destination can be any territorial area such as a village, a town, a city, a region or a country. According to Baker (2007: 26), a destination brand is the totality of perceptions, thoughts and feelings that customers hold about a place while destination branding refers to the organising principle that involves orchestrating the messages and experiences associated with the place to ensure that they are as distinctive, compelling, memorable, and rewarding as possible. Successful destination brands reside in the customer's heart and mind; clearly differentiate themselves; deliver on a valued promise; and simplify customer choices (ibid).

While nation branding aims at forming a complete picture of a nation, destination branding aims at promoting specific regions or critical components of the tourism industry within a country (Hemstrom et al., 2006:27). Anholt (2004) defines place branding as "...the practice of applying brand strategy and other marketing techniques and disciplines to the economic, social, political and cultural developments of cities, regions and countries" (cited in Kerr, 2006:278). The branding of a destination enables the customer to readily identify it and distinguish it from its competitors.

A country could be associated with particular benefits or activities that are offered by a destination. These benefits act as a cue for decision-making regarding purchases (Kaplanidou \& Vogt, 2003:2). The perceived value of a place is affected by a country's characteristics such as commerce, politics, culture, sport, science and tourism.

\subsection{Tourism marketing}

Tourism marketing seeks to increase the number of visitors or tourists to a particular place, which could be a village, town, city, region or country. Nowadays people visit places for a variety of reasons, among them for business, leisure, medical, sporting or cultural purposes. Tourism has a central role to play for nation branding and sustainable development for a country, to a large extent owing to the fact that tourism is probably the world's largest industry, while tourism marketing is usually the only way countries market themselves to the outside world (Anholt, 2005).

Besides the fact that it usually has the loudest voice in branding the nation, as it also mostly has the biggest budgets and greatest experience in marketing (Anholt, 2007:26). Tourism promotion has an advantage above other forms of country communication, since it has the 'permission' to address publics directly; tourists are used to and expect to be wooed (Anholt, 2007:87). Anholt further argues that the tourism industry has traditionally been the only industry where a government minister and a marketing manager will work side by side. However, there is usually an unclear relationship between the public sector and private enterprises with regard to tourism marketing. Nation branding, however, extends beyond the familiar realm of tourism marketing and encompasses a range of other objectives (Dinnie, 2008:19).

\subsection{The concept of nation branding}

As globalisation continues to increase at an accelerating rate, competition between countries has emerged as one of the major challenges facing contemporary governments across the world. With about 194 countries, the global market has 
become a battlefield for skilled workforce, FDI, tourism income, trade and export opportunities, and international influence. Presently, the notion of a global village and competition among nations has reached a new level of sophistication, (Cromwell \& Kyriacou, 2001:1). This reality has compelled countries to come up with innovative marketing and branding strategies to promote their uniqueness in order to become the destinations of choice for investments, tourists, business and immigration.

One strategy that nations are embracing in order to build and sustain their global competitiveness and ensure national economic development is nation branding. Nation branding is not a new phenomena. Nations have always branded themselves through their mythology, anthems, symbols, currency and names (Skodra, 2010:1). Mi (2009:1) affirms that "...nation branding encompasses activities from country naming through to all the collected activities of the country". It is a managed process of building brand equity, brand image and a sustainable and competitive country reputation.

According to Anholt (2007:3), nation branding is the same as 'competitive identity', and he defines it as "...the systematic process of aligning the actions, behaviours, investments, innovations and communications of a country around a clear strategy for achieving strengthened competitive identity".

Cromwell \& Kyriacou (2001:1) point out that governments are tasked with the economic and political development of their countries. National development cannot be achieved in isolation of the international community, as markets and foreign policies compete in the international arena. The complexity of these elements and a nation's political, economic, legal and cultural environment all contribute to a nation's identity and image (ibid).

Nation branding, according to Kaneva (2011:118), is "...a compendium of discourses and practices aimed at reconstituting nationhood through marketing and branding paradigms". Nation branding includes a variety of activities, which range from 'cosmetic' operations such as the creation of national logos and slogans, to efforts to institutionalize branding within structures by creating governmental and quasi-governmental bodies that oversee long-term nation branding efforts. The most ambitious architects of nation branding envision it as "... a component of national policy, never as a 'campaign' that is separate from planning, governance or economic development" (Anholt, 2008:23).

According to Fan (2009:6), nation branding is "... a process by which a nation's images can be created, monitored, evaluated and proactively managed in order to improve or enhance the country's reputation among a target international audience". Szondi (2008:5) defines nation branding as "...the strategic self-presentation of a country with the aim of creating reputational capital through economic, political and social interest promotion at home and abroad". Analysing Szondi's definition, Dinnie (2009:1) argues that "...the focus on self-presentation and promotion derives from a public relations perspective and emphasizes the importance for a nation to actively manage its reputation rather than passively allowing external parties to impose their own brand onto the nation".

Lo0 and Davis (2006:198) lament that "...every nation is a brand and most nations have had their brands made for them. The nation brand could have been developed deliberately or by default, formed from a myriad of different sources such as word of mouth, education, mass media, travel, product purchases and dealings with its people". Increasingly, nations around the world are embracing nation branding to differentiate them on the world stage, and to bolster their economic performance (Dinnie, 2008:23).

Different countries have adopted different strategies in order to confront specific challenges, which they face. More and more countries around the world are embracing nation branding in order to differentiate themselves on the world stage and to strengthen their economic performance, primarily in terms of exporting, inward investment and tourism. Countries as culturally and geographically diverse as Germany, South Korea, New Zealand, Scotland, Egypt, Britain and Spain have judged it worthwhile to develop nation-branding strategies (Dinnie, 2008:23).

\section{Findings and Discussion}

The following sections discuss the findings of the study. These findings are discussed within the context of the research questions.

\subsection{What is the current context of the brand Zimbabwe and its projection on the global map?}

In order to be able to develop a framework for the re-branding of Zimbabwe, it was imperative for the researcher to establish current perceptions of Zimbabwe internally and externally. A majority of non-Zimbabwean respondents believe that Zimbabwe has a negative image on the international map and most of them acknowledged that this perception has largely been shaped by information emanating from the international media. These findings highlight the fact that the international media plays a vital role in forming and shaping peoples' perceptions about various countries. This finding 
also indicates the fact that Zimbabwe has been generating negative publicity in the international media, which has contributed to the erosion of the country's brand equity.

Corroborating the foreign respondents, a majority of Zimbabweans also acknowledged that the country's image on the international map is negative. Most of them attributed this perception to their personal experience in the country, and also to information emanating from the media about developments in the country. Most respondents also agreed that Zimbabwe has been negatively portrayed in both local and international media and that this has damaged the country's reputation as a destination for tourists and inward investment. This finding agrees with Kotler \& Gertner's (2002:251) assertion that the media is a heavy-weight when it comes to influencing people's image about certain places and countries.

From these findings about Zimbabwe's negative image on the international map, the researcher argues that the successful re-branding of the country should have the transformation of the country's international image as one of the key objectives of the process. For the media to report positively about the country there should be positive stories originating from the country and currently this is still a major challenge, especially for the government of Zimbabwe, which generally views the private media as a hostile stakeholder. It is, therefore, vital for the country to engage both local and international media in order to create a mutually beneficial relationship that is built on trust and common interests. However, for this milestone to be achieved there is a need for the situation on the ground to be transformed.

These findings about the negative perceptions of Zimbabwe on the international market also corroborate with the findings of the 2011 Country Brand Index (CBI) produced by Future Brand. In this index, Zimbabwe is ranked 112, which is the second last position on the index, while Pakistan occupies the last position. In Africa, the CBI ranked Zimbabwe at number 23 out of 52 countries. The $\mathrm{CBI}$ assesses the strength of a country brand in much the same way as any other brand. It measures awareness, familiarity, preference, consideration, advocacy and active decisions to visit or interact with a country (Future Brand, 2011). Zimbabwe's position on the CBI index indicates that the country is viewed negatively by international audiences, and the country is classified in the same category with other "pariah and lawless" countries such as Pakistan, Iran and Afghanistan. With this ingrained negative perception, re-branding Zimbabwe is indeed a transformative and challenging process.

Most Zimbabweans agreed that the country should be re-branded and that they are also willing to participate in the process. Most of the respondents also affirmed that the country needs a complete overhaul of its socio-economic and political systems. This affirmation also corroborates the topic of this particular study: 'Rebranding Zimbabwe: $A$ Transformative and Challenging Process'. According to most respondents, for Zimbabwe to emerge as an attractive and successful brand, there is a need to transform the whole fibre of Zimbabwean society, that is, the political, legal, economic and social systems. The transformation of a whole country is a complex and challenging process, which takes time to execute and achieve the required results.

\subsection{What process should guide the re-branding of Zimbabwe?}

Having reviewed the literature on nation branding strategies and techniques, analysed cases of successful and unsuccessful nation branding, and considered the findings from the questionnaire survey and the interviews, the researcher proposes the transformational model below (Figure 1) for the re-branding of Zimbabwe in order for the country to overcome the challenges it is currently facing.

This model can also be applied to any other country that has been in a situation of prolonged socio-economic and political crises. This model provides answers to the following research questions, which were also propagated in the introductory chapter:

- How can Zimbabwe be re-branded?

- What is the desired impact of nation branding in Zimbabwe?

- How can re-branding be used as part of the process to overcome the challenges of transforming Zimbabwe?

- How can re-branding improve Zimbabwe's image? 
Figure 1: Proposed transformational model for the re-branding of Zimbabwe

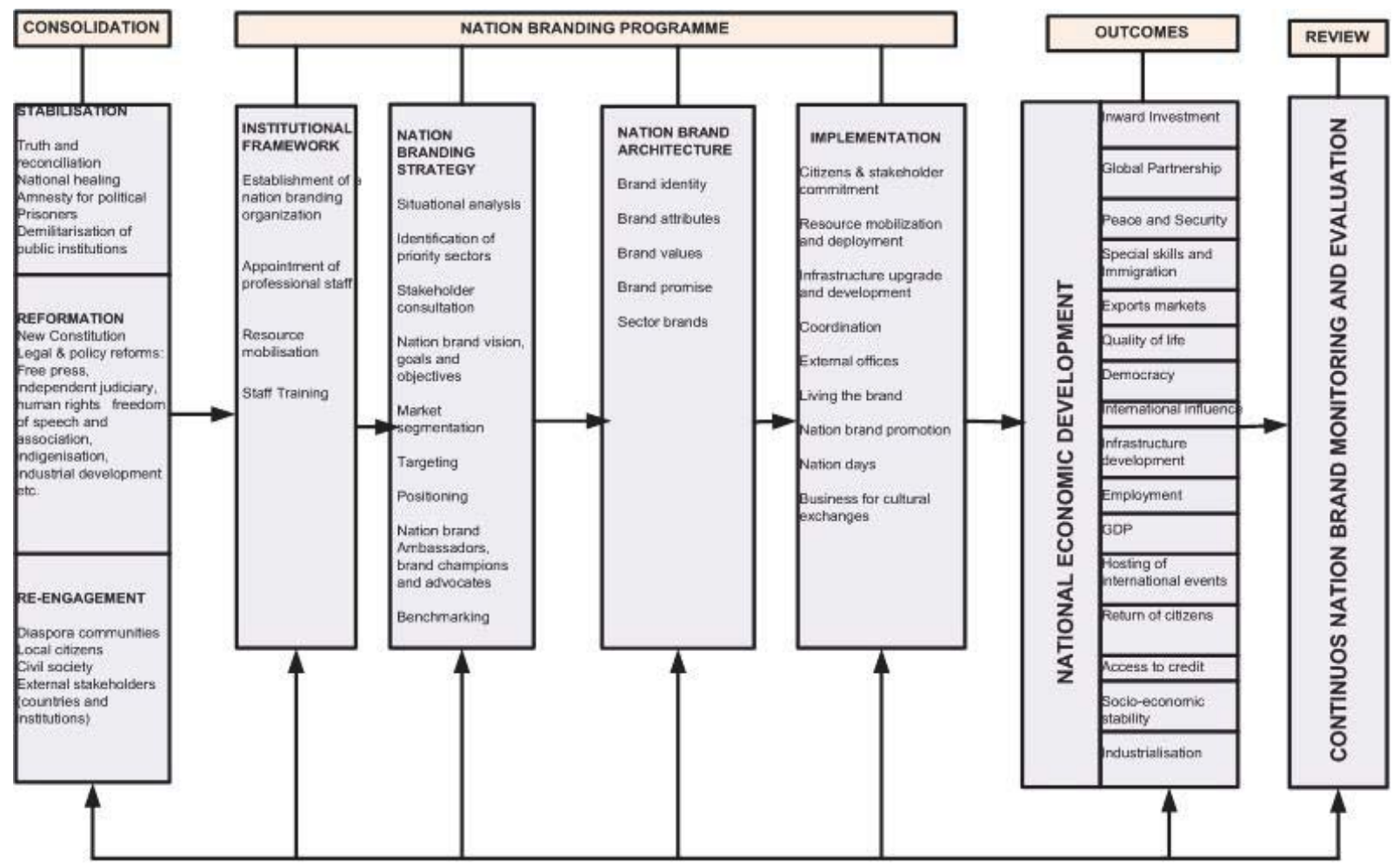

\subsubsection{Consolidation}

The transformative process to re-brand Zimbabwe should start with consolidation. This involves initiatives to stabilise the macro and micro environments, appropriate and adequate policy reforms and re-engagement with domestic and international stakeholders who had become disenchanted with the country.

As part of stabilisation, there is a need for the country experience a process of reconciliation and national healing in order to create unity in the country, which is a prerequisite for successful nation branding. Currently, many public institutions are being led by current and former members of the defence forces, which has led to the militarisation of public institutions. As part of the stabilisation process, there is also a need for the demilitarisation of state institutions by appointing professional civilian managers and leaders. The release of political prisoners will also go a long way towards building bridges among political opponents.

Legal and policy reforms in Zimbabwe are also urgently required if the country is to return to normalcy. There is a need for reforms that will provide for the following:

- A democratic constitution that provides citizens with adequate freedom to participate in national economic development;

- Free and fair elections;

- An open media environment that allows free speech and the free exchange of ideas;

- A judiciary that is independent of the executive and the legislature;

- Policies that allow citizens to participate in national economic development;

- Policies to create an open and free society; and

- Policies to curb corruption and abuse of public resources.

Zimbabwe should also re-engage with the international community as part of the re-branding initiative. A successful and effective nation branding is dependent on the establishment and management of healthy and mutually beneficial relationships with as many stakeholders as possible.

In this regard, the country needs to re-engage with countries such as US, UK, Australia, New Zealand, Canada and many others. The country should also re-engage with international institutions such as the IMF, WB, EU and the 
Commonwealth. These countries and institutions had lost confidence Zimbabwe and imposed "targeted" sanctions against the country's political and business leaders. The imposition of sanctions has had adverse negative effect on the economy and the image of the country on the global map, and this makes re-engagement with these stakeholders a vital undertaking.

\subsubsection{Nation branding programme}

This phase involves the actual designing of the nation brand strategy and its implementation. The starting point of the nation branding programme should be the formation of an organisation to spearhead and manage the re-branding exercise. The majority of the respondents in the questionnaire survey and the interviews supported the idea of the creation of an independent institution to spearhead the re-branding of Zimbabwe

The next step will involve the development of the actual nation branding strategy, which includes identification of internal and external stakeholders, development of the nation brand vision, goals and objectives. As part of the strategy development process, there is also aneed to segment the markets, target specific niche markets and position the nation brand. This stage will also involve appointment of nation brand ambassadors, champions and advocates to be the faces of the nation brand, and to facilitate its marketing and promotion.

\subsubsection{Eligible brand ambassador(s) for Zimbabwe's nation brand}

One of the critical components of a nation branding strategy is the appointment of nation brand ambassador(s) for the country. The literature review noted that the nation brand ambassador(s) is/are the face(s) of the brand and must have a positive reputation and be able to positively impact on other stakeholders and audiences internally and externally. Dinnie (2008: 72) asserts that brand ambassadors could be a potentially cost effective way of promoting a nation. The study found out that, individually, Strive Masiyiwa is the most preferred ambassador for Zimbabwe, followed by Prime Minister Morgan Tsvangirai and Oliver Mutukudzi respectively.

The choice of Masiyiwa, a successful businessman in the telecommunications industry, as the preferred ambassador for the nation brand, to a larger extent, indicates the respondents' desire to have a new face to spearhead the country's re-branding initiative. This choice also highlights the respondents' belief that the process to rebrand Zimbabwe should not be politicised, hence the choice of a private citizen.

To a larger extent, the preference of Masiyiwa also indicates the desire of the respondents to see the private sector playing a leading role in national affairs. It is an indication of a preference for a new beginning and a breakaway from the past. However, creating a new beginning in Zimbabwe is a challenging endeavour due to the fact that there are some significant sections of the Zimbabwean society that still believe in the old order and are prepared to defend it to the best of their abilities.

This grouping is comprises the presidency, the security forces' leadership, ZANU (PF) party, and the governmentcontrolled media. This viewpoint is also reinforced by a minority of respondents who indicated that all is well in Zimbabwe and that the country does not need to be re-branded.

Developing a coherent and effective nation brand requires the whole country to be able to present a united front, and to speak with one voice. However, this remains a major challenge in the case of Zimbabwe because the political environment is highly polarised and the nation is divided along political, religious and ethnic dimensions. The literature review also identified politics and conflict of interest as one of the challenges of branding a nation and this is indeed one of the challenges that the people tasked with the re-branding of Zimbabwe will need to tackle.

However, with regard to the choice of the nation brand ambassador(s), it is imperative to point out that a majority of respondents did not prefer the identified potential brand ambassadors. They chose the 'other' category and this arguably highlighted their preference for other citizens to be brand ambassadors. Hence, the researcher argues that respondents expect the process of re-branding to be led by other citizens instead of the current crop of leadership, and this may be interpreted as a vote of no confidence in the current political leadership.

The respondents clearly affirmed that any credible nation branding initiatives must be led by exemplary leaders. The researcher, therefore, strongly argues that the re-branding of Zimbabwe should be as inclusive as possible and must be underpinned by clearly defined national objectives and not by the objectives of a specific political party.

The process to re-brand Zimbabwe should also involve as many stakeholders as possible and these stakeholders should include the private sector, civil society, academia, labour unions, religious groups, representatives of international organizations, Zimbabwe's embassies and foreign trade missions, diplomatic corps and many others, as part of diverse symbiotic partnership to design, build and sustain a successful nation brand for Zimbabwe. 


\subsubsection{Nation brand strategy implementation}

Implementation involves the actual execution of the overall strategy and will encompass the following issues:

- Resource mobilisation and deployment;

- Participation and involvement of the country's citizens in various activities and programmes to promote the brand;

- Infrastructure upgrade and development;

- Creation and management of external offices;

- Citizens actually living the brand and fulfilling the brand promise to tourists, investors, skilled immigrants, exports markets and so on; and

- Promotion of the nation brand through advertising, public relations, publicity, cultural, political and economic diplomacy, sponsorships, exhibitions, organized tours and so on.

\subsubsection{Nation branding programme outcomes}

If successful, the implementation of the nation branding initiative should lead to national economic development through outcomes such as the following:

- Increased inward investment;

- Establishment of mutually beneficial partnerships with strategic foreign partners;

- Establishment and sustenance of lucrative export markets;

- Increased tourist arrivals and spend;

- Attraction of skilled human resources;

- Return of citizens who had emigrated;

- Improved standards of living and quality of life for the country's citizens;

- Better international image, recognition and influence;

- Rapid industrialization and development of excellent and modern infrastructure;

- Reduction in unemployment;

- Increased GDP and stable economic environment;

- Hosting of international events; and

- Improved credit rating and access to cheaper finance.

\subsubsection{Monitoring and Review}

This is the final stage in the proposed model for the re-branding of Zimbabwe. The re-branding of a country through a transformative process is not a once-off activity and therefore there is need for continuous monitoring and review of the process to ensure that the nation branding goals and objectives are being met and that there is actual transformation on the ground. Continuous monitoring and review affords the authorities to take remedial action were the desired outcomes have not been achieved.

\subsection{Recommendations}

In view of the above results and findings the study proposes the following recommendations:

\subsubsection{Creation of a conducive and enabling environment}

Zimbabwe should create a stable socio-economic, political and legal environment before embarking on any nation branding initiative. The current macro and micro environment in Zimbabwe is not conducive enough for the development and sustenance of a strong and successful nation brand. As highlighted in the proposed model above, there is a need for stabilisation, reformation and re-engagement before implementation of nation branding initiatives.

There is a need for major transformation of Zimbabwean society, which should transcend the social, political and economic environment. The purpose of this transformation is to create a conducive and enabling environment for national economic development, in general, and nation branding activities, in particular. 
There is also a need to have an independent and diverse media that is allowed to report on developments in the country without fear or favour. The judiciary should also be allowed to exercise its constitutional obligations without political interference. The country should also develop and implement policies that attract investment and tourism in order to create employment and to facilitate economic development. For example, the current indigenisation policy, which seeks to give Zimbabweans a 51\% stake in all foreign owned businesses is scaring investors away from the country.

A strong and effective brand should be underpinned by adequate and attractive infrastructure such as good road networks, transport systems, telecommunications systems, education, and health systems.

\subsubsection{Re-engagement with the international community}

Zimbabwe should re-engage the international community with the sole purpose of repairing damaged relationships in order to forge new partnerships. The country cannot afford to operate in isolation in the current environment of globalisation. Zimbabwe should re-engage with countries and institutions such as the USA, European Union, Commonwealth, IMF, WB, Australia, Japan and others in order to create positive relationships with them. In order to develop a competitive nation brand, the country must not be under any form of economic or political sanctions because being in such a situation creates a negative image for the country and ultimately damages its nation brand.

\subsubsection{Citizens' participation in national affairs}

The citizens of any particular country are its greatest asset. Zimbabwe should ensure that its citizens at home and abroad participate in the country's affairs irrespective of their political views. Currently, the country has legislation such as POSA and AIPPA, which limits the right of citizens to freedom of speech and association. Many citizens have been arrested and tortured for not complying with this legislation. However, there is a need to create an environment that allows citizens to freely participate and contribute to national discourse without fear of arrest by the authorities. This recommendation corroborates Anholt's (2007:29-30) view that creation of a common purpose in the country leads to establishment of a competitive identity for the nation brand.

Creation of such an environment will ultimately be a rallying point for the democratisation of the country and allow all citizens to participate in the socio-economic and political affairs of the country. Finally, when re-branding a nation, internal buy-in is a prerequisite for external buy-in.

\subsubsection{Development of a nation brand before sector brands}

There is a need to develop a nation brand first before developing sector or sub-brands. Currently, Zimbabwe has a tourism brand that preceded a nation brand instead of vice-versa. It is imperative to develop a nation brand first, and this brand will create the overall framework, direction and boundaries within which sub-brands such as tourism, telecommunication, education, transport and other sector brands can be established and managed.

\subsubsection{Diaspora mobilisation and engagement}

Zimbabwe has millions of citizens who live in countries as far afield as the US, UK, Australia, SA, Botswana, New Zealand, Germany and many other countries. These citizens are either economic and/or political refugees and most of them are skilled professionals who have much potential to contribute to the socio-economic development of the country.

Generally, the ZANU (PF) establishment regards the bulk of the diaspora community as opposition activists and views them with great suspicion. This scenario, has therefore, led to the marginalisation of this community in national affairs, including the denial of their right to vote in national elections.

However, this study found out that a majority of Zimbabwean diasporans are still committed to the country and are willing to contribute to the resuscitation of the economy. It is, therefore, vital for the Zimbabwean government to mobilise and engage with all its citizens abroad with the sole objective of encouraging them to participate in the country's economic development and nation branding initiatives. This recommendation affirms the view that nations can benefit from using their diaspora to promote the home country abroad (Dinnie, 2008: 72).

This can be done through the creation of diaspora networks in different host countries to support the re-branding of the country. Besides being brand ambassadors and brand advocates in their host countries, disporans can also contribute to the country's development through investments at home, as well as by providing much needed, but scarce technical and managerial skills. 
As a result of their exposure to the international environment, many diasporans possess essential experience and skills that are needed for the rejuvenation of Zimbabwe. The researcher, therefore, strongly argues that diasporans are probably one of nation branding's most influential and significant stakeholder groups.

\subsubsection{Institutionalisation of nation branding activities}

As alluded to earlier, branding a nation is a complex and resource consuming exercise that should be undertaken within a clearly institutionalised environment. The researcher recommends that there is a need to create an institution that is specifically dedicated to the designing, development and management of a nation brand for Zimbabwe.

There is a need to establish an independent statutory body funded by the national treasury to spearhead and manage the process to re-brand Zimbabwe. This organisation should be apolitical and should be operated by qualified professionals drawn from different sectors of the economy. The board of directors of this institution should be constituted by high ranking representatives from both the public and private sector. For example, this institution could be built along the lines of Brand SA, which has four cabinet ministers and directors from leading corporations on its board.

The institution tasked with the re-branding of Zimbabwe must be given adequate independence to manage its operations, including the hiring of staff and engagement with internal and external stakeholders such as academics, nation branding consultants and other experts. As this institution will be a public-private sector partnership, the latter must be allowed to provide much needed technical expertise in the areas of branding and marketing, which may not be available in the public sector. The level of representation from the public sector will also demonstrate the level of political will and commitment to the process of re-branding Zimbabwe.

\subsubsection{Nation brand ambassadors}

As part of the nation branding strategy, the country should appoint credible, believable and reputable individuals as nation brand ambassadors, brand champions and brand advocates.

Current efforts to re-brand Zimbabwe are being spearheaded by Mutambara. Much as he is a highly qualified robotics professor, he lacks the credibility and national appeal to be a nation brand ambassador for Zimbabwe. Mutambara is also currently embroiled in a legal battle for control of the smaller MDC party and the case is yet to be adjudicated by the Supreme Court. Not only is this legal battle tarnishing his image, it may also signal the end of his political career in government, if judgment is delivered against him.

The country should have individuals of the highest level of integrity to champion and represent the nation brand. These individuals should be unsoiled, reputable and capable of uniting the country towards a common agenda and purpose to build a strong and successful nation brand for Zimbabwe. The nation brand ambassadors should also be exemplary and be able to 'live the brand'.

\subsubsection{Establishment of offices in targeted countries}

This study also recommends that as part of the nation branding strategy, it is vital for the country to establish foreign offices in targeted countries. These offices should be located in countries that are major source markets for tourists, investors, skilled human resources, exports and so on. In this regard, the researcher corroborates with Papadopoulos (2004:45) who points out that small and developing countries, given their limited assets, strengths and media exposure, should focus on niche markets instead of treating the market as global.

The foreign offices should also collaborate and coordinate with the country's embassies and trade missions in the respective countries in terms of marketing the country and providing information to the target market. The people who will staff these offices must be adequately trained on the nation brand's values and the general objectives of the country's branding exercise. These individuals must also be capacitated with enough knowledge of the country, its products and services in order to be able to provide credible and valuable first-hand information on request.

\subsubsection{Benchmarking against best practices}

This particular study acknowledges that across the world, there are cases of successful and unsuccessful nation branding. The case studies analysed in Chapter 4 are testimony to this fact. The study, therefore, recommends that before a country embarks on a re-branding exercise, it is advisable to carry out study tours of those countries that have gone through the same experience in order to draw some lessons from their experience instead of trying to 'reinvent the 
wheel'.

The purpose of such visits is to learn from the nation branding best practices and to avoid repeating the same mistakes made by these countries when they re-branded. Benchmarking provides a platform for knowledge transfer and enables the country to 'hit the ground running' instead of going through a learning curve, which can be a time-consuming and expensive exercise. However, the researcher advises that benchmarking should be conducted with an analytical appreciation of the contextual and environmental differences between the various countries, because what worked in one country may not be possible in another.

\section{Directions for Future Research}

The conclusion of this research study both answers the study's questions and generates new ones. As with any study, the findings obtained in this thesis display some shortcomings and these limitations should be recognised when interpreting the findings of this thesis, while also recognising opportunities that they present for further research. This study was exploratory in nature and, therefore, provides the following promising avenues for future studies in the area of nation banding.

\subsection{Role of the diaspora communities in nation branding}

Diaspora communities are an essential and significant stakeholder in nation branding. However, no previous research has been conducted to establish the role and nature of their contribution to nation branding activities. It is, therefore, important for research to be conducted in future in order to establish how the diaspora contribution can be harnessed and integrated in nation branding strategy development, implementation and sustenance.

\subsection{Impact of political leaders on the nation brand}

One of the challenges of branding a nation is the need to overcome political differences within the country. However, no research has been conducted to establish the impact of political leadership on nation branding. The need for this kind of research has been necessitated by the realisation that politics can support or hinder nation branding activities and that the government is probably one of the most important stakeholder institutions in the nation branding process. Furthermore, many political leaders end up being synonymous with their countries, for instance, many respondents associate the brand Zimbabwe with Mugabe, the country's president and vice versa. It is, therefore, imperative for future research to focus on establishing the impact of national political leaders on nation brands.

\subsection{How to integrate nation and sector brands}

Nation brands have been equated to corporate brands, since they are umbrella brands that have other sub-brands beneath them. For example, a nation brand may have other sector brands such as tourism, export, manufacturing and transport sub-brands under its ambit. However, there is a research gap in terms of a model or framework that explains how a nation brand can be integrated with its sub-brands in order to build sustainable brand equity for the nation brand and its affiliate brands.

\section{Conclusion and Implications}

This study has clearly articulated that nation branding has become a vital strategy for national economic development, especially in this contemporary environment where countries are involved in aggressive competition with each other for markets, tourists, inward investment, skilled human resources, international influence and so on. It is more than apparent that in order to survive, countries, even if small and developing, should undertake efforts to create, manage, modify and enhance their nation brands. This is especially so for countries that face prolonged or sustained social, economic and political crises. There is also no doubt that Zimbabwe is in a pernicious state and the country should be re-branded. For the re-branding of Zimbabwe to be successful, it must be preceded by major transformation of the country's socioeconomic, political and legal systems in order to create a conducive and enabling environment. Without this, rebranding the country is tantamount to "applying make-up on a frog and hoping that it will look beautiful". Re-branding a country is not a cosmetic undertaking to spruce up the country's image at home and abroad, but rather it should be a comprehensive national economic development strategy that seeks to create national competitive advantages, national 
brand equity and improved quality of life for the country's citizens through sustained economic growth, peace and prosperity. Zimbabweans are generally willing to participate and support the process of re-branding the country, hence the country should return to normalcy and everything will fall back into place.

\section{References}

Anholt, S. (1998). Nation-brands of the 21st Century. Journal of Brand Management, vol. 5, no. 6, pp. 395-406.

Anholt, S. (2002). Foreword. Brand Management, vol. 9, no. 4-5, pp. 229-239.

Anholt, S. (2005). Brand new justice. Revised ed. London: Elsevier Butterworth Heinemann.

Anholt, S. (2006). Editorial. Why brand? Some practical considerations for nation branding. Place Branding, vol. 2, no. 2, pp. 97-107.

Cromwell, T. (2008). Why nation branding is important for tourism. Branding Nations. East-West

Communications. Available at http//eastwestcomms.com. [Accessed 8 Aug. 2009].

Domeisen, N. (2003). Is there a case for national branding? International Trade Forum, 14.

Fan, Y. (2005). Branding the nation: What is being branded? Journal of Vacation Management, vol.12, no.1, pp. 5-14.

Florek, M. (2005). The country brand as a new challenge for Poland. Place Branding, vol.1, no.2, pp. 205-214.

Gudjonsson, H. (2005). Nation branding. Place Branding, vol.1, no.3, pp. 283-298.

Kay, M.J. (2007). Strong brands and corporate brands. European Journal of Marketing, vol.40, no.7 and 8, pp. 742-760.

Kotler, P and K.L. Keller. (2006). Marketing management. 12th ed. New Jersey: Pearson Education.

Mihailovich, p. (2006). Kinship branding: A concept of holism and evolution for the nation brand. Place Branding, vol.2, no.3, pp.229247.

Msele, F. (2007). A critical analysis of the current state of knowledge of nation branding. Cranfield University.

Ndlela, D. (2009). Zim Splurges cash to manage international perception. Available at http://www.bizcommunity.com/Article/ 238/82/23942.html. [Accessed 22 Apr. 2009].

O'donovan, D. (2004). Opinion piece: Where is place branding heading? Place Branding, vol.1, no.1, pp.30-32.

Olins, W. (2002). Opinion piece: Branding the nation: The historical context. Brand Management, vol.9. No.4 and 5, pp.241-248.

Olins, W. (2000). Available at www.wallyolins.com. [Accessed 29 Aug. 2009].

O'shaughnessy, J. AND N. O'shaughnessy. (2000). Treating the nation as a brand: Some neglected issues. Journal of Macro Marketing, vol.20, no.1, pp.56-64.

Pantzalis, J. and C.A. Rodrigues. (1999). Country names as brands: Symbolic meaning and capital flows. Montclair State University.

Papadopolous, N. (2004). Place branding: Evolution, meaning and implications. Place Branding, vol.1, no.1, pp.36-49.

Papadopolous, N. and L. Heslop. (2002). Country equity and country branding: problems and prospects. Journal of Brand Management, vol. 9, no.4, pp.294-314.

Porter, M. (1990). The competitive advantage of nations, 1st Ed. London and Basingstoke: Macmillan Press Limited.

Rendon, J. (2003). 'When nations need a little marketing.' New York Times: November 23.

Szondi, G. (2007). The role and challenge of country branding in transition countries: The central and eastern European experience. Place Branding and Public Diplomacy, vol.3, no.4, pp.8-20.

Temporal, P. (2001). Why Asian countries need branding. Available at www.asiainc.com. [Accessed 14 Aug. 2009].

Teslik, L.H. (2007). Anholt: Countries must earn better images through smart policy. Council on Foreign Relations. Available at http://www.cfr.org/publication/14719/. [Accessed 4 Apr. 2009]

Teslik, L.H. (2007). Nation Branding Explained. Available at http://www.cfr.org/publication/14776/. [Accessed 26 May 2009].

Vaknin, S. (2008). Nation branding and place marketing. Branding nations. East-West Communications. Available at http://www. eastwestcoms/. [Accessed 13 Jul. 2009].

Vatahov, I. (2006). Branding a country. Mass Media Matters, Episode 2, no.1. 